\title{
Japan's Forest Resources and Household Fuels
}

\author{
by Norio Tanaka
}

(National Forest Resources Council)

SYNOPSIS :-The grave situation of our forest resources is well indicated by the fact that the native lumber production surpasses the forest growth by the ratio $2: 1$. As the import can not be expected so much, the surest meaures are reforestation, development of the aboriginal forests, together with rationalization of consumption, especially of the domestic fuels.

\section{エネルギ給源中に占める石炭の地位}

一一眧和 29 年 6 月 15 日特別䧿演会一

\section{日本石炭拹会 天 日 光一}

要旨：エネルギ対策樹立の根本は，資源の国内自給率，安定度からみて何を主供給源とするかにす る。わが国エネルギ資源の賦存状況は「水力・石炭複合型」で, 消費構成からみても石炭のウェィトが 圧倒的に大きい。国際情勢によつて供給量を左右されめすい外国の石油にあまり依存せず，炭鉱の合理 化により，国两炭の割高是正，供給不安の一掃が恒久的対策である。

エネルギ問題と石炭について，いささか石炭の側に 立つ者としての所見を述べたいと思う。

今日エネルギ対策は，わが国の産業並びに国民生活 に頗る重大な影響を㩔すものであるから，わが国の土 ネルギ資源の賦存状況を基調としてェネルギ対策の樹 立を，石炭業界としては图に関係各方面に要請してき たのである。

近時，石炭と重油との間に調整を要する状況となつ たので，石宸業界以外の方面からも綜合エネルギ対策 確立の要が叫ばれるにいたつた。

そこで通産省に設置された，座業合理化審議会にお いてもエネルギ部会が設けられ，また日本動力協会， 経済団体連合会などにおいても綜合エネルギ対策問題 が採り上げられ，研究され始めた。

\section{I エネルギ対策の基本的方向}

エネルギ対策としては，その供給源の大宗を何に設 定するかが最も重大な問題である。すなわち，長期に わたつてェネルギ資源として国内自給率の大小，安定 度合を主とし，さらに人口問題や国民所得や，国際収 支上の利害得失など諸般の点をも考慮検討して，慎重 に決定すへきであつて，軽々しく一時的の難易，利害 より断し，あるいは世界的通勢なりとして，事情を異
にする他国の傾向に乗ずへきではないと思う。

\section{II エネルギ資源の賦存および消費と石岸}

しからば，わが国における土ネルギ資源の賦存状沇 は，どのようになつているかというと

$\begin{array}{ll}\text { 水 力 } & 54 \% \\ \text { 石 炭 } & 34 \% \\ \text { 薪, 石油なぞ } & 12 \%\end{array}$

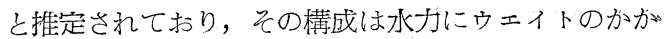
つた「水力，石炭複合型」だといわれるのは，けだし 適切な表現であつて，このことはわが国の地質，地 形，気候などに基くのである。

しかしながら，現実のエネルギ消費構成は，開発の 難易の関係から水力の開発が石炭の開発よりも遅れ。 いるため，石炭消費のウ土イトが圧倒的に大きく，昭 和 27 年度ではむしろ水力と石宸の比率は次のとおり大 れ替つている状潜である。

$\begin{array}{lll}\text { 石 } & \text { 炭 } & 53.6 \% \\ \text { 水 } & \text { 力 } & 27.5 \% \\ \text { 薪, 未 } & \text { 炭 } & 11.1 \% \\ \text { 石 } & \text { 油 } & 7.7 \% \\ \text { 天然 ガ } & 0.1 \%\end{array}$

昭年9～11年では石孷が $66.0 \% ，$ 水力が16.3\%となつ 
ているから，水力の比重は増大しているが，な抢石炭 が圧倒的なウェイトを占めている。

次に世界のエネルギの消費構成をみても

\begin{tabular}{|c|c|c|c|}
\hline & 1947年 & (石炭換算, 100 万t & \\
\hline 石 & 炭 & 1,349 & $54 \%$ \\
\hline 石 & 油 & 652 & $26 \%$ \\
\hline 水 & 力 & 220 & 9 \\
\hline そ & の 他 & 273 & $11 \%$ \\
\hline & 訫 & 2,494 & 1 \\
\hline
\end{tabular}

となつており，やはり石炭が過半のウェイトを占めて いる。

近来エネルギ源としての石炭時代は終つた，いまや 石油時代であるとの声も一部にはあるが，これは石油 の伸び方を誇示したもので市つて，実態は依然として 日本のみならず，世界を通じて過半のウェイトは石崖 によつて占められていることは前述のとおりである。 それでは，わが国のエネルギ源の過半を負担している 石炭の埋蔵量はどれ程あるか。昭和 7 年商工省の石炭 埋藏量調査概要によると約162億 $t$ となつているが，こ のうち実収確実量は63億 9,000 万t と算出されている。 その当時から現在までの, 採掘量は約 8 億 $t$ であるか ら，なお 50 数億 $t$ 残すことになり，今後毎年 5,000 万t づつ採掘するとしても 100 年以上続くわけである。そ の間には埋蔵炭層の新発見もあろうし, また技術の進 歩による実收確実量の増大も期待し得上う。

また水力については昭和 21 年, 同じく商工省の調へ によると

$\begin{array}{lrc}\text { 最大出力 }(1,000 \mathrm{~kW}) & \text { 常時出力 }(1,000 \mathrm{~kW}) \\ \text { 既開発 } & 6,055 & 2,673 \\ \text { 工事中 } & 535 & 241 \\ \text { 未開発 } & 13,142 & 4,232 \\ \text { 包藏水力 } & 15,732 & 7,146\end{array}$

であつて，現在な打包蔵水少の $40 \%$ 開発されている にすざない。今後電源開発 5 力年計画なに゙によつて， さらに開発されてゅくものと思われるが，水力開発に は地勢や，開発経費などに基く制抳によつて自から限 度があるから，石炭は将来も全ェネルギ需要の過半を 負担するもの之思われる。

\section{III エネルギ疽源としての石油}

一両年来, 石油類がェネルギ源として急調子に使用 が増大していることは認められる。しかしながら，石 油は国内賦存量が少ないためきわめて自給率が低く， 遣澸ながらその需要の $90 \%$ 以上を海外に低存しなけれ ばならないのは避けられない宿命である。

現在, 世界的に石油は生産過剩の傾向にあつて，量
的には輸入に支障がないようではあるが，一朝国際情 勢に変化をみれば,需給関倸は緊張して, 輸入に支障を きだすべきことは既往の深刻椧戦な経験の教えるとこ ろである。国際情勢によつて供給量を左右され易い外 国の石油を，わが国土ネルギ源として過度に依存す心 きでないことはあえて多言を要しないことであろう。

また当今石油類と国内宸の洒格を比較し, 前者が割 安であるとの利点が挙げられるが, 輸入品が割安な点 のみをもつて輸入すへしとするならば，単に石油類に 限らず，他の多くの物資も輸入に侯つべきこととなる わけである。しかしわが国としてはかくのごとき輸入 一辺倒の挙に出で得ないし，またそうしてはならない ことは言うまでもないことである。割安輸入物資の使 用增大によつて生産価格が引き下げられ，直ちに輸出 が増大するとの観察も，あまりにも局部的，公式論的 な考えかたであると思われる。貿易の実情はえのよう に単純ではないことを示している。外貨保有高は必要 最低線をも割らんとする危険状態に瀕している現在, 冷敩な現実に即してゅかなければならない。

石油類が石炭に比して約 1 割程度割安だといわれて いるが，海上運貢が国際情勢によつて昂騰すれば，割 安の利は立ち所に消隇し去る。このことは近々 3,4 年 前の海上運貨の情勢を想起すれば明白であろう。すな わち昭和 26 年は前年よりも一挙に 8 割強も值上りし, その翌年は 3 割ほど值下りしたというように常に浮動 している。

\section{タンカー世界中心航路平均運貨}

$\begin{array}{lr}\text { 1950年12月 } & 101.0 \\ \text { 1951年12月 } & 184.8 \\ \text { 1952年12月 } & (-) 33.0 \\ \text { 1953年12月 } & \text { (一) } 39.6\end{array}$

また海上運賃の朂滕は別として，現在停止されてい る重油の輸入関税を関税定率法の本則に還して，これ を徽収することになれば割安の度合は激減するであろ う。

精製用原油さえも輸入関税の免税措置を講じている 国は，世界32力国中わずかに英，加，伊とわが国の 4 カ国であり，重油について輸入関税をとらないのは恐 らく日本だけであろう。豊富な石炭, 褐炭資源と乏し い石油資源の上に立つている点で，わが国ときわめて 近似している西独の場合をみると，重油関税は $100 \mathrm{~kg}$ 当り 12.90 ドイッマルク（邦貨換算 1,105 円， $1 \mathrm{kl}$ 当り， 11,000円）という驚くべき高率を課しており，輸入禁 止的意味をも持つといわれている。それに反して重油 
はもちろん，原油にも色税措置が採られているのがわ が国の現状である。

石炭側に立つ者として卒直に言えば，重油が無税で あるのに対し，石炭には法人税，鉣産税，固定資産税 等々，各種の税金が課せられている実情であるから， まずこれら石炭への税負担をはずし，同等の立場にた つて比較しなければ不適当だと考える。また国内炭と 輸入重油や輸入炭との価格の此較については，公定為 替レートと実勢為替レートからの論議もあるが省略す る。

\section{IV 政府のエネルギ対策}

政府は土ネルギ問題を検討し，かつ最近の諸状勢を 勘案した結果，去る 3 月 30 日閣議において，「わが国 のエネルギ消費は，その資源の賦存状況抢よび国際収 芳上の観点からみて，石油などのごとく国際状勢によ り供給量を左右され易い資源に依存すべきでなく，基 本的には電力おょび石炭の使用に重点を置くべきであ る」との方釬を閣議了解事項として決定した。

なお，3月1日に衆議院通産委員会におおても綜合 燃料対策を採り上げ，「恒久対策として，わが国にお けるェネルギ資源賦存状沉抢よび日本経済自立達成の 見地よりみて，基本的には水力電気の綜合開発と石炭 生産の能率化に重点を置くべぎあるが, 石炭の経済 的，合理的生産にも一定の限界があるから，これを越 える需要の増大に対しては重油をもつて充当する。当 面の対策として，石孷の生産目標は 4,480万t（一部貯 炭を含む）と予定し，原油抢よび熏油の輸入は差し当 りこれに見合う程度に止め, 石炭再転換を図る」と決 議した。

上記の閣議決定に基き, 当局では「重油需給調整要 綱」を定め, エネルギ源の海外低存度に一線を劃した 対策を推進せんとしている。近年，にわかに重油使用 に転換した方面には不便，不利の点もあろうが，わが 国のエネル乎対策としてはけだし大筋からみて，適切 な方向であると考える。

\section{$\mathrm{V}$ 炭価引下げについて}

一方国内炭の割高是正, 供給不安の排除の要請につ いては，政府がつとに考究しているところであり，石 炭業界もまた鋭意努力を重悋つつる。すなわち，炭 価割高の是正については，連年努力を続けており，現 に昭和24年統制解除後の合理化努力の成果も過少評価 すべきではなく，理論原価は着々切下げられている。

$\begin{array}{lll}\text { ○昭和28年上期理論原価( } \mathrm{A}+\mathrm{B}) & 6,078.93 & \text { (C) } \\ \text { ○昭和28年上期实績原価 } & 4,711.00 \text { (D) } \\ \text { ○合理化総額 (C-D) } & 1,367.93(23 \%)\end{array}$

しかし何分にもその割高の主因が，戦前，戦中の濫掘 に端を発し，戦後は激减した出炭面の回復に寧日なき 状態であつて，宸砵の自然條件の劣悪化に対㾈して坑 内外の合理的整備, 若返り工事を施す睱がかつたこ と，また長期にわたる統制炭価時代を通じて低物価政 策の犠牲のもとに赤字炭価をよざなくされ，年々借大 金の額は増加し，28年 9 月末に抢ける大手石炭会社19 社分の借入金は次のごとく龙大な額に達している。

\begin{tabular}{|c|c|}
\hline 長期借入金 & 411億8,400万円 \\
\hline 借入金 & 222億5,600万円 \\
\hline 訫 & \\
\hline
\end{tabular}

(昭和28年 9 月末現在日本石炭協会々員19社分)

また為替レート設定後の各種資材や動力料金，運貨 などの值上りが炭砸企業内の吸收を遥かに上迴つたこ と，あるいは税制の重圧等々……要するに遠因, 近因, 自然條件，経理條件の悪化，重圧が錯綜累積している ので，企業内部の合理化，機械化，堅抗開さくなど万 般にわたつて不断の努力が払われているにもかかわら ず，その效果が削減せられて大きく表面に現われない のが実情である。石炭生産コスト引下げの努力を今後 も継続することはもとより当然であるが，とくに大方 の理解在御影いしたい重要事は，石炭鉙業はいまや年 産5,000万七 の生産能力を有するにもかかわらず，29年 度のごときは外部事情に影響せられて4,300万七程度に 出岸が抑制されていることで，今後重油の使用が增大 すれば，出炭規模はさらに縮少を色れない。このこと は単に、コント引下げを目途とする堅坑開さくなど, 炭破合理化工事の推進を阻害するのみならず，か元つ て石炭生産費の昂騰をきたすことになり，国家的にき わめて我心すへきき重大事である。

わが国エネルギ源の大宗である石炭の出炭規模を縮 少に追、込み，生産コストの低下どころか，胡騰をき たすがごときは，国策上採るべからざるは言を俟た始 ことであり，あたかも療養中の患者に誤つて衰弱剈在 投ずるがごとき愚挙に類するものである。

石崖鈗業は地上工場々は趣を異にし，一度生産力を 低下せしめたのち, 回復を図るには少なから好年月と， 巨費走要することは，終戦直後の辛酸走徵するまでも なく明らかなところである。また業界においては深刻 な数次の争議と巨額な資金を費して企業整㣁を実施し， 現在では 31 万人の労務者と 5 万人の職員を擁している が，生産縮少に追い迄まれ，さらに人員整理をよぎな 
きにいたれば，その困難と梁刻さは宸吰所在 の南町村財政問題に止らず，ひいては失業問 題として, 社会不安と, 不測事態の惹起も杞 憂と断しえなないとは，最近の紙上の報道か らも予想しうるところであろう。

な打国内炭の供給不安を唱えるものがある が，これは一部の特殊石炭について炭咴スト 時に醸し出される一時的現象であつて，これ に対しては石炭業界は，これら特殊㞸の増産 計画を立て供給不安を釀し出すことのないよ うに，周到に妢力を払つている。

最後に全体論として考察すれば, 何分, 年間 5,000万tの出炭能力を持ちながら, せめて一 応の石炭鉱業の安定條件として，まず 4,800 第 1 図 石炭生産事情一覽図 万七 は掘らせて鿓い度いと念願要請しているのにかか わらず，わずかに4,300万t 位しか見込め䅐況である から，石炭の供給不安を招来するがごときことはない

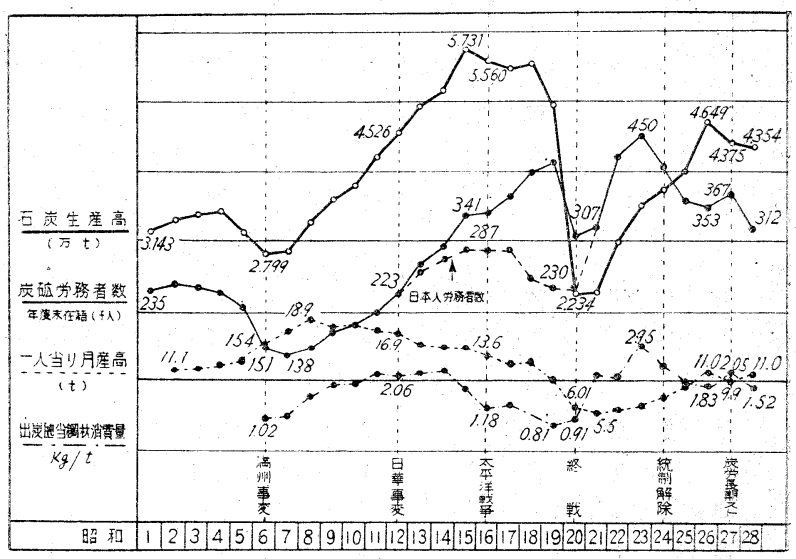

わけである。

なお，末尾に石炭鉣業の現状，趨樊などに関する若 干の資料を揭げる。御参照願えれば幸甚である。

\section{第 1 表 わが国炭砿の諸條件变化一覽表}

種別項

宸 層 $\left\{\begin{array}{lllll}\text { 厚 } & & & \text { 巳 } \\ \text { 炭 } & の & \text { 品 } & \text { 位 } \\ \text { 選 } & \text { 炭 } & \text { 步 } & \text { 留 }\end{array}\right.$

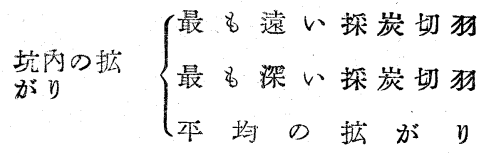
坑道延長 $\left\{\begin{array}{l}\text { 㚾 道 稳延 長 } \\ \text { 年產1000 t当り坑道延長 }\end{array}\right.$ 切狗\{探炭切狗長さ

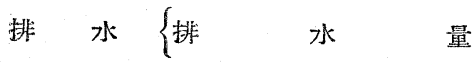

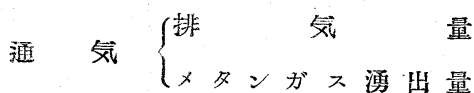

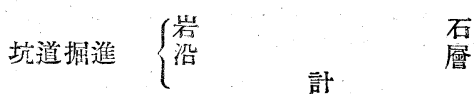
労衝時間 $\{$ 埰炭夫本均就業時間

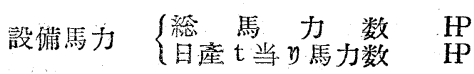

細

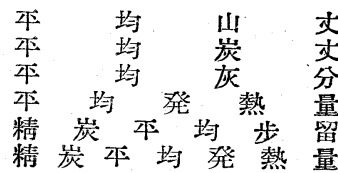

坑口只の坑道距離 運搬系統の段数 坑口を基準とした深さ 平均探掘深度 (坑口基準) 坑口加らの平均坑道距離

目

$\begin{array}{llll}\text { 維 } & \text { 持 } & \text { 坑 } & \text { 道 } \\ \text { 連搬 } & \text { 坑 道 } \\ \text { 維 } & \text { 持 } & \text { 坑 } & \text { 道 } \\ \text { 運 } & \text { 搬 } & \text { 坑 } & \text { 道 }\end{array}$

稳延 長

棇出炭に対する払出炭割合

每分総排水量 (年間本均) $\dot{\mathrm{m}}^{3} /$ 分 出炭 $\mathrm{t}$ 当り排水量 $(\%) \mathrm{m}^{3} / \mathrm{t}$

每分総排完量 (年間平均) $\mathrm{m}^{3} /$ 分 出炭 $\mathrm{t}$ 当り排気量( ”) $\mathrm{m}^{3} / \mathrm{t}$ 出炭 $1000 \mathrm{t}$ 当楓進延長

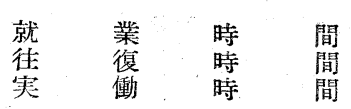

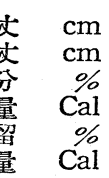
$m$ 段 $m$ $\mathrm{m}$

$\mathrm{km}$ $\mathrm{km}$ $\mathrm{m}$
昭和 9 年 12 昭和 24 年 12 月末現在 A 月末末現在 B

$\mathrm{B} / \mathrm{A} \%$ $\mathrm{m}$

\begin{tabular}{|c|c|}
\hline $\begin{array}{r}187 \\
158 \\
28 \\
5,559 \\
76 \\
6,487\end{array}$ & $\begin{array}{r}183 \\
144 \\
35 \\
4,956 \\
70 \\
6,320\end{array}$ \\
\hline $\begin{array}{r}4,100 \\
6 \\
500 \\
222 \\
1,616\end{array}$ & $\begin{array}{r}5,000 \\
10 \\
752 \\
275 \\
1,983\end{array}$ \\
\hline $\begin{array}{r}524 \\
272 \\
52 \\
27\end{array}$ & $\begin{array}{r}767 \\
390 \\
99 \\
50\end{array}$ \\
\hline $\begin{array}{r}17,500 \\
73\end{array}$ & $\begin{array}{r}15,300 \\
68\end{array}$ \\
\hline $\begin{array}{l}693 \\
7.8\end{array}$ & $\begin{array}{r}1,049 \\
10.9\end{array}$ \\
\hline $\begin{array}{r}104,000 \\
4,700 \\
17.5\end{array}$ & $\begin{array}{r}171,000 \\
10,500 \\
25.0\end{array}$ \\
\hline $\begin{array}{r}5.7 \\
28.2 \\
33.9\end{array}$ & $\begin{array}{r}9.4 \\
36.3 \\
45.7\end{array}$ \\
\hline $\begin{array}{r}11 \text { 時16分 } \\
50 \text { 分 } \\
8 \text { 時35分 }\end{array}$ & $\begin{array}{l}8 \text { 時 8分 } \\
1 \text { 時15分 } \\
6 \text { 時 } 1 \text { 分 }\end{array}$ \\
\hline $\begin{array}{r}204,000 \\
5.5\end{array}$ & $\begin{array}{r}393,000 \\
14.5\end{array}$ \\
\hline
\end{tabular}

（通癄省石炭局調査による） 
第 2 表 㞸硡機械化の進度と能率推移表

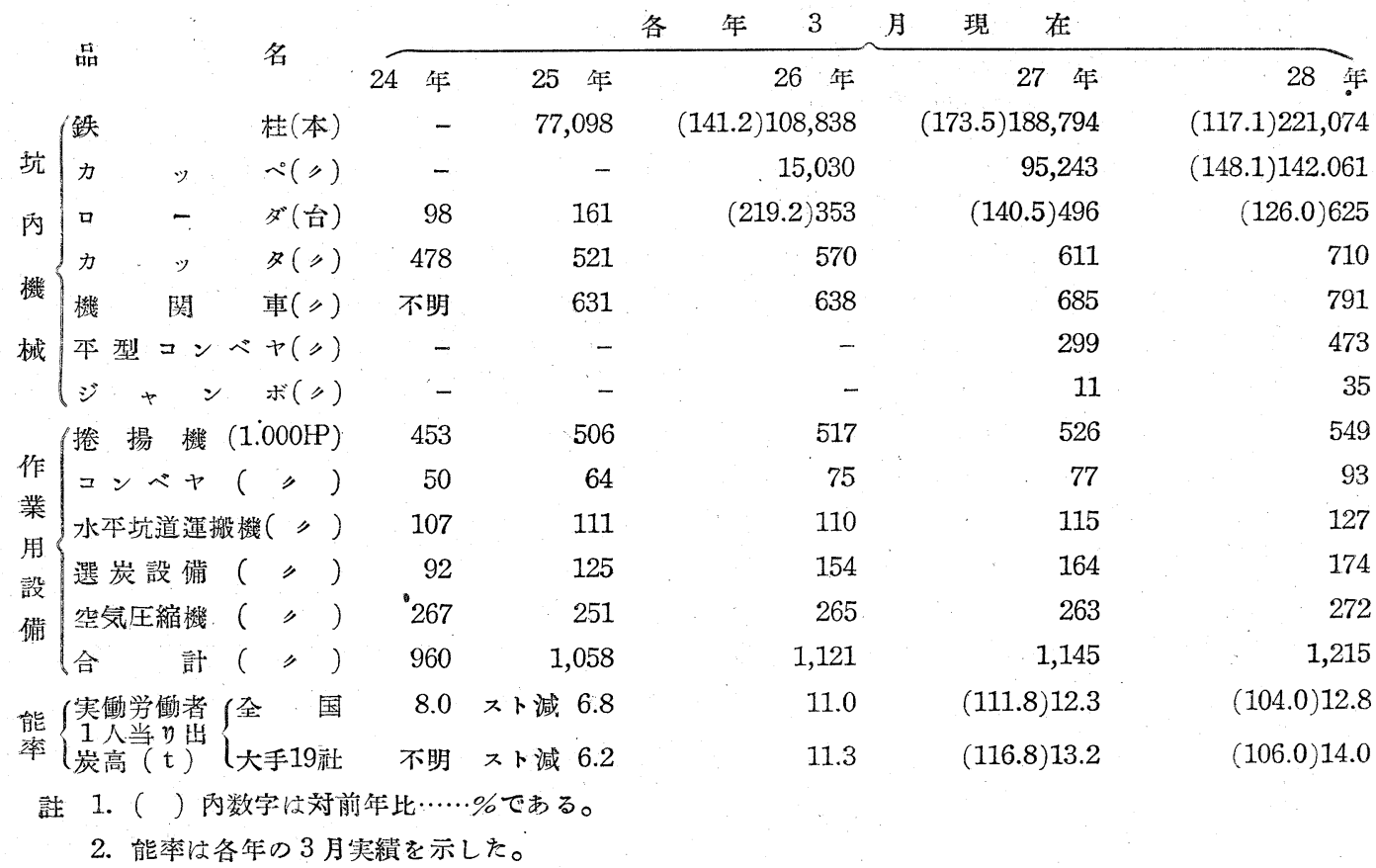

第2図石炭生産力推移図
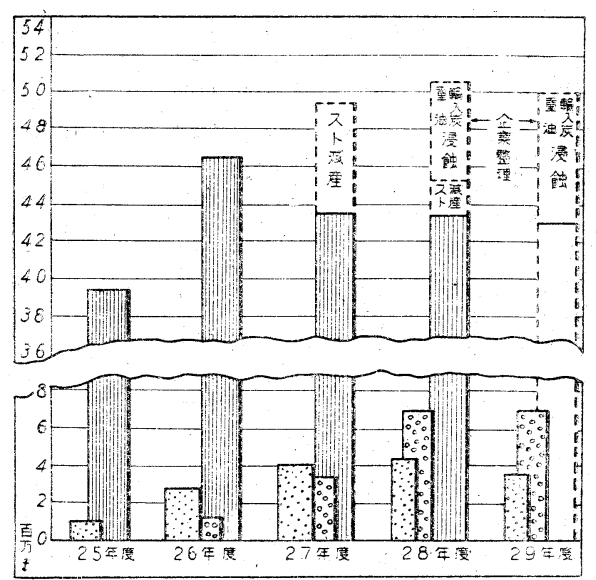

敦石炭生産力。

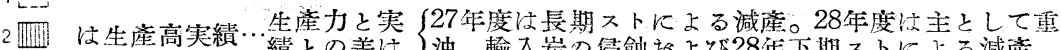

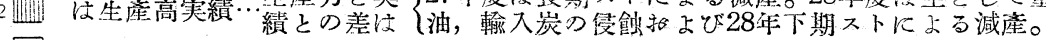

3 目輸入炭入着实績拒よび予想。

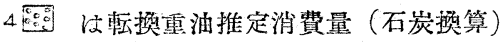

(単位 $1,000 t$ )

\begin{tabular}{|c|c|c|c|c|c|c|}
\hline 出炭生笑 就 & 39,330 & $46,49 \overline{0}$ & $\begin{array}{l}49,640 \\
43,747\end{array}$ & $\begin{array}{l}52,500 \\
43,538\end{array}$ & （見达） & $\begin{array}{l}50,000 \\
43,000\end{array}$ \\
\hline 入 & 996 & 2,629 & 4,035 & 4,164 & & 3,717 \\
\hline 転 換 重 & - & 1,251 & 3,495 & 6,925 & & 6,92 \\
\hline
\end{tabular}




$$
\begin{aligned}
& \text { 范 }
\end{aligned}
$$

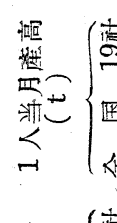

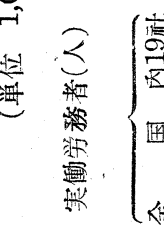

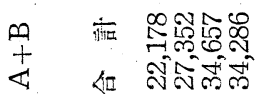

$$
1 \stackrel{\infty}{N}
$$

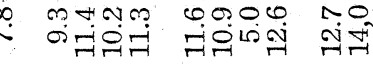

COLN HOOO NMNO Nol

$1000 \mathrm{~N}$

유율

$00^{\circ}$

ㅂํำ

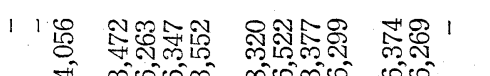

मี กิ

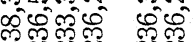

พิ

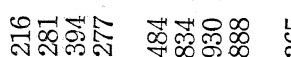

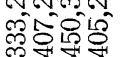

हीजीए

나있용ㅇㅇ

象论

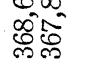

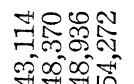

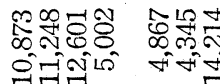

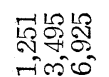

나요용

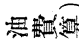

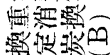

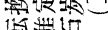

( $k-1$

孚角望

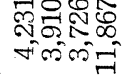

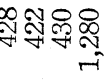

我你

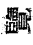

I

桨

解

兴

펭

形

掞

III

6

4

논

楼

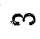

矮
酒

.$$
\text { 粱 }
$$

r

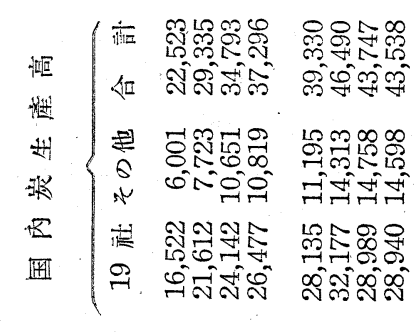

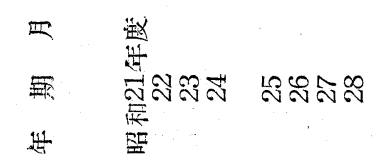

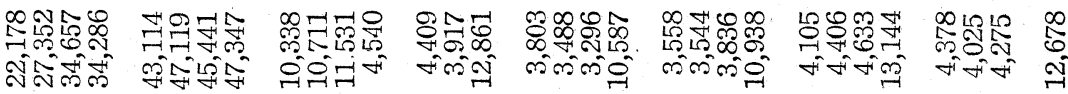

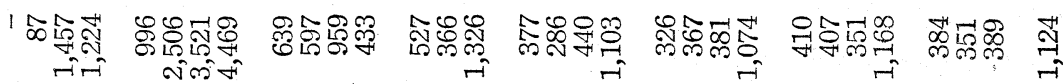

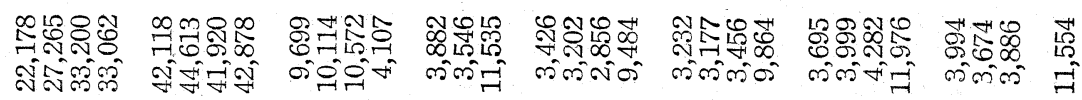

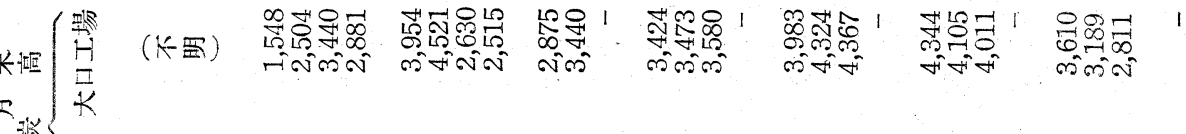

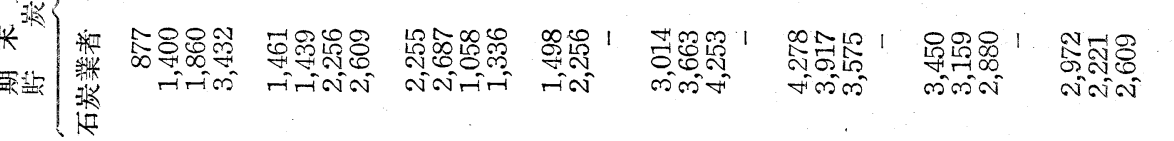

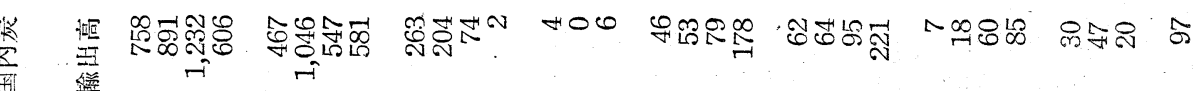

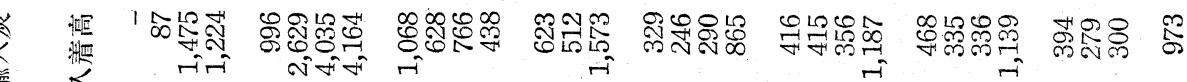

遥

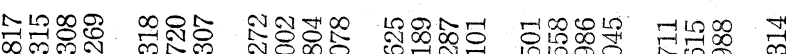

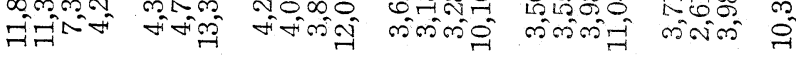

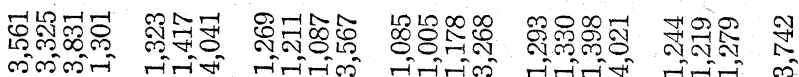

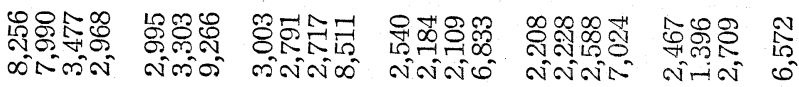

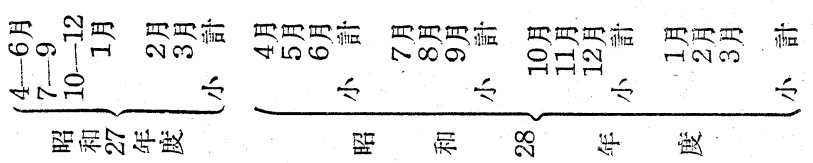




\title{
第 3 図 国內炭需要分野に対する輸入炭と重油の影響推移図
}

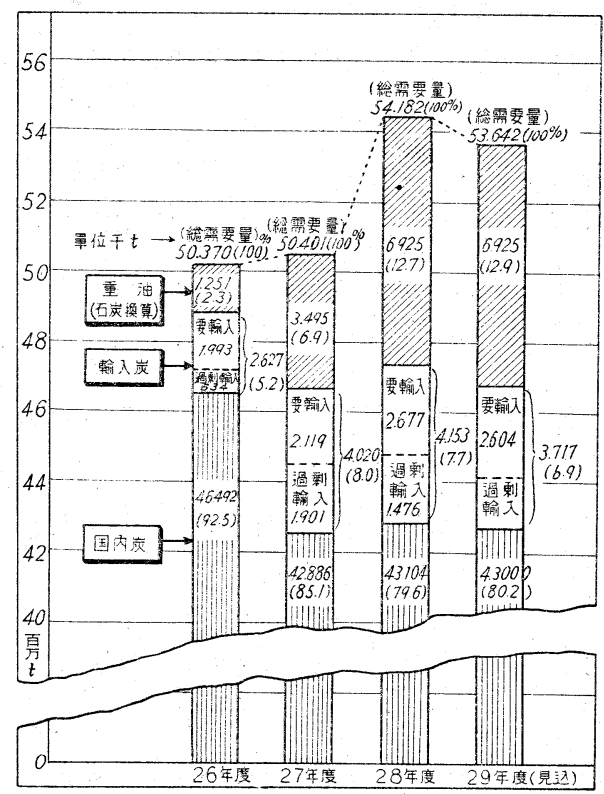

註 1) 国内炭和よび輸入炭纹荷没数量である。

2）重油々石炭消費さ重油消費に切替无た使用者の重油消費む石炭に掺算したもので市る。

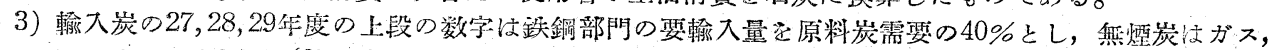
コークスの必要量（27年度13.5万t，28年度13.5万 $t$, 29 年度 15.5 万 t ）とし，その他は必要ないもの とした場合の要輸入量である。(29华度輸入炭棇量371.7万七经 29.3 .30 作成，通產省石炭局「昭和 29 年度石炭需給見通し」Kよる輸入量である)

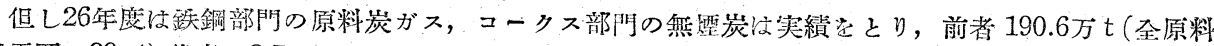
炭需要の $39 \%$ ) 㷋者文 8.7 万でこの他の輸入炭々必要ないものとした場合の要輸入量が上段の199.3万 $\mathrm{t}$ である。

4) 重油 (石炭換算) の29年度数量注28年度の需要量と同量を29年度需要量とした。

\section{The Position of Coal in the Nation's Energy Supply}

\author{
by Kōichi Tennichi \\ (Japan Coal Association)
}

SYNOPSIS:-The national energy policy is to be established upon the self-sufficiency and stability of its resources. The potential energy of our resources is of "Compound waterpower-coal type". Coal also predominates in the list of energy consumption. The author believes it a permanent policy to stabilize the coal production by rationalization, not depending upon the imported oil whose supply is seriously affected by the changing international relations. 